\title{
IMMUNOBLOTTING ANALYSIS OF SOMATIC COMPONENTS OF DIROFILARIA IMMITIS
}

\author{
OGE H.*, OGE S.*, YILDIRIM A.**, KIRCALI F.*** \& KARA M.****
}

\section{Summary:}

SDS-PAGE analysis of Dirofilaria immitis extracts demonstrated the complexity of somatic protein component of adult male similar to that of adult female worm. Western blot analysis showed six major peptide bands of $85,66,42,20,16.2$ and $14.5 \mathrm{kDa}$ recognized in the sera of infected dogs. Western blotting sera from dogs with Dirofilaria immitis infection suggest that antigenic components in the low molecular weight region may be related to the anti-parasitic mechanism of the host.

KEY WORDS : Dirofilaria immitis, dog, SDS-PAGE, Western blot.
Résumé : ANALYSE PAR IMMUNOBLOTTING DES COMPOSANTS SOMATIQues DE DIROFILARIA IMMITIS

L'analyse en SDS-page des extraits de Dirofilaria immitis démontre une complexité des protéines somatiques des mâles adultes semblable à celle des vers femelles. L'analyse en Western Blot de ces protéines avec des sérums de chiens infectés a identifié six bandes principales de 85,66,42,20, 16,2 et 14,5 kDa. Les résultats obtenus par cette technique utilisant des sérums de chiens infectés par la filaire suggèrent que des composants de faible poids moléculaire pourraient être liés aux mécanismes antiparasitaires induits chez l'hôte.

MOTS CLÉS : Dirofilaria immitis, chien, SDS-page, Western blot.
D irofilaria immitis is an important filarial parasite and well-known cardiovascular parasite of canids, the importance of which is usually associated with morbidity and mortality in the domestic dogs. In addition, D. immitis, has zoonotic potential; it may undergo partial development in humans (Laird \& Smith, 2001). The natural cycle of the maturation of the dog heartworm involves the development of bloodborne microfilariae into infective third-stage larvae $\left(\mathrm{L}_{3}\right)$ in the mosquito vector (Grieve et al., 1983). There is a well recognized need for improved diagnostic techniques for canine dirofilariasis. Only a small proportion of infections can be detected clinically. Amicrofilaremic infections occur in up to $67 \%$ of $D$. immitis-infected dogs (Calvert, 1987), and the phenomenon of filariasis without microfilaremia is well described in humans (Laird \& Smith, 2001).

The most common diagnostic procedures for heartworm infections in the dog are detection of microfila-

\footnotetext{
* Department of Parasitology, Faculty of Veterinary Medicine, Ankara University, Ankara.

** Department of Parasitology, Faculty of Veterinary Medicine, Erciyes University, Kayseri.

**:* Department of Parasitology, Faculty of Veterinary Medicine, Kocatepe University, Afyon.

***** Department of Parasitology, Faculty of Veterinary Medicine, Kafkas University, Kars.

Correspondence: H. Oge. Fax: +90-312-3164472

E-mail: oge@veterinary.ankara.edu.tr
}

remia or detection of circulating antigens secreted primarily by adult female worms (Calvert, 1987). These methods have proven to be relatively insensitive for detection of heartworm infections due to the most almost complete absence of microfilaremia and relatively frequent occurrence of male-only infections or single female worm infections. Tests that detect antibody to filarial antigens are positive in dogs but this increased sensitivity is offset by a loss of specificity, and the presence of antibody to filarial antigens does not prove infection. These problems have pointed out the need for a more sensitive, yet specific, test to detect infections of dogs.

In the recent years, SDS-PAGE and Western blot techniques have been used in the field of parasitology. They created a new era in immunodiagnosis, which greatly reduces cross reactions and which is a very important step in early diagnosis of the disease. However, they still need to be standardized.

The aim of the present work was to determine specific protein bands for heartworm infections in dogs by Western blotting.

\section{MATERIALS AND METHODS}

n this serological study, dogs were 4-9 years old age. Worm burdens of infected dogs ranged from three to 20 (two to $12 \mathrm{female/one} \mathrm{to} \mathrm{eight} \mathrm{male}$ adult $D$. immitis). 


\section{ANTIGEN PREPARATION}

Adult female and male D. immitis worms were obtained from the heart of the dogs infected with canine heartworm and washed with saline several times. The parasites were placed in a small pestle and mortar and treated with added to appropriate amounts of liquid nitrogen. Then, the antigens in the pestle were pulverized. After the nitrogen was allowed to evaporate, the worms were homogenized in TBS containing protease inhibitors (1\% deoxycholic acid and $5 \mathrm{mM}$ ethylenediaminetetra-acetic acid). The extract were placed in eppendorf tubes and centrifuged at $13,000 \mathrm{rpm}$, for 30 minutes at $4^{\circ} \mathrm{C}$ to remove insoluble components. The supernatants were recovered as somatic extracted antigens of male worms (MEX) and female worms (FEX) (Heath D.D., 2000, personal communication).

\section{SERA}

To diagnosis of naturally infected dogs, microfilaremia and heartworm antigen levels were monitored by the polycarbonate filter-acid phosphatase histochemical staining test and by ELISA, respectively. Blood samples were taken from positive and negative dogs and sera obtained from these dogs stored at $-70^{\circ} \mathrm{C}$. In addition, commercially obtained normal dog serum was used.

\section{SDS-PAGE AND IMMUNOBLOT}

Antigen fractions were separated electrophoretically by SDS-PAGE (Laemmli, 1970) in a gel (5\% stacking $+12 \%$ separating). Proteins were visualized with silver stain technique. Western blotting was conducted following SDS-PAGE, and somatic components were transferred to nitrocellulose membrane with a Transblot apparatus (Bio-Rad). Sera were used at 1:60 dilution. To determine the extent of immunoglobulin binding peroxidase conjugated rabbit anti-dog IgG diluted 1:2000 was used. Bands were visualized by incubation in $\mathrm{DAB}$ (3,3'-diaminobenzidine) substrate for 5-10 min.

\section{RESULTS}

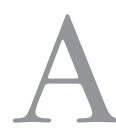

11 dogs of the infected group were positive for heartworms as revealed by necropsy examination. In analysis of extracted proteins by SDSPAGE, many protein bands were observed at 6.5 to $205 \mathrm{kDa}$. There were 33 bands in MEX and 28 bands in FEX (Fig. 1). The present results clearly demonstrated that MEX and FEX possess many protein bands in their somatic material. SDS-PAGE analysis of $D$. immitis extracts demonstrated a complexity of protein components of adult male similar to that of female

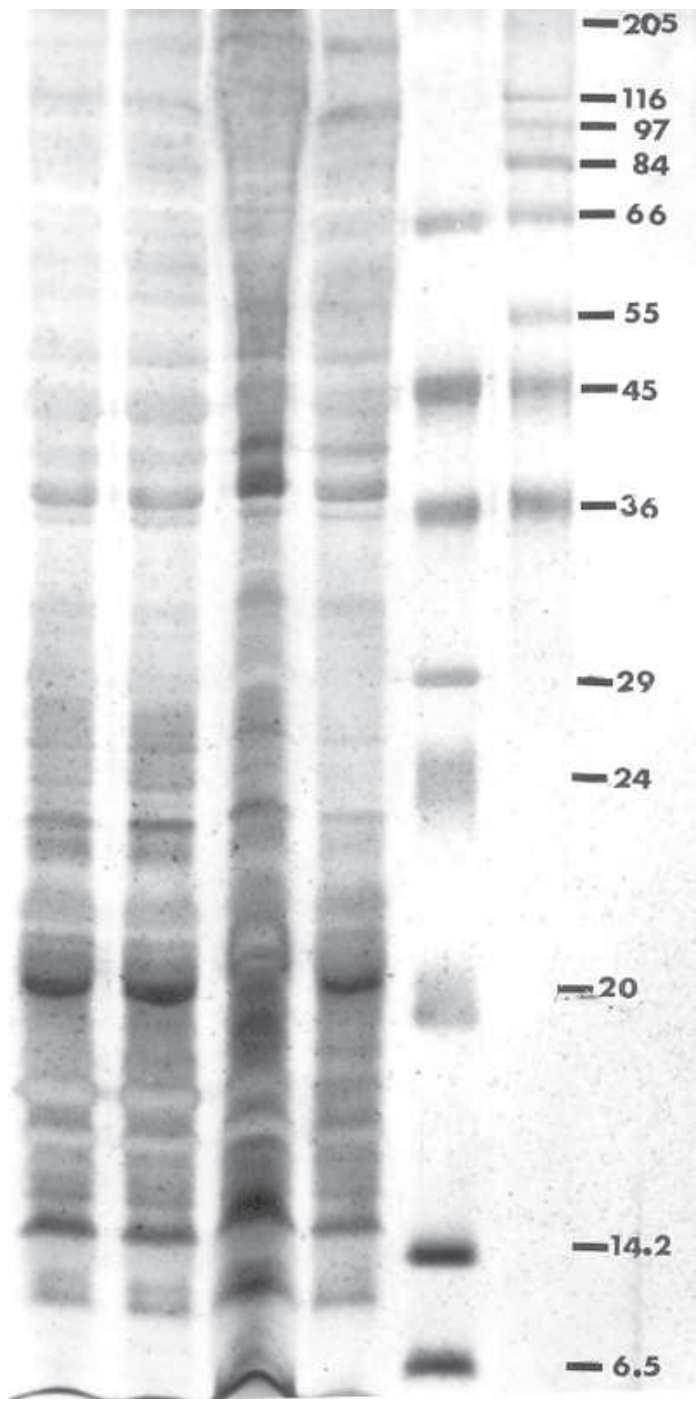

Fig. 1. - SDS-PAGE electrophoresis of somatic extracts from female and male Dirofilaria immitis. The positions of molecular weight standards are indicated along the right margin of the figure.

worms. Western blotting demonstrated a lot of bands in MEX and FEX. The sera markedly react not only with high molecular weight material but also with low molecular weight materials in MEX and FEX. Specific protein bands for heartworm infection were determined as 85, 66, 42, 20, 16.2 and $14.5 \mathrm{kDa}$ (Fig. 2). These bands were not revealed in the control and commercially obtained normal dog serum. Non-specific bands present in infected and uninfected dog sera were also observed.

\section{DISCUSSION}

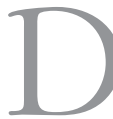

iagnosis of D. immitis in dogs is generally performed by finding microfilariae or antigens in blood. Although some reports have been 


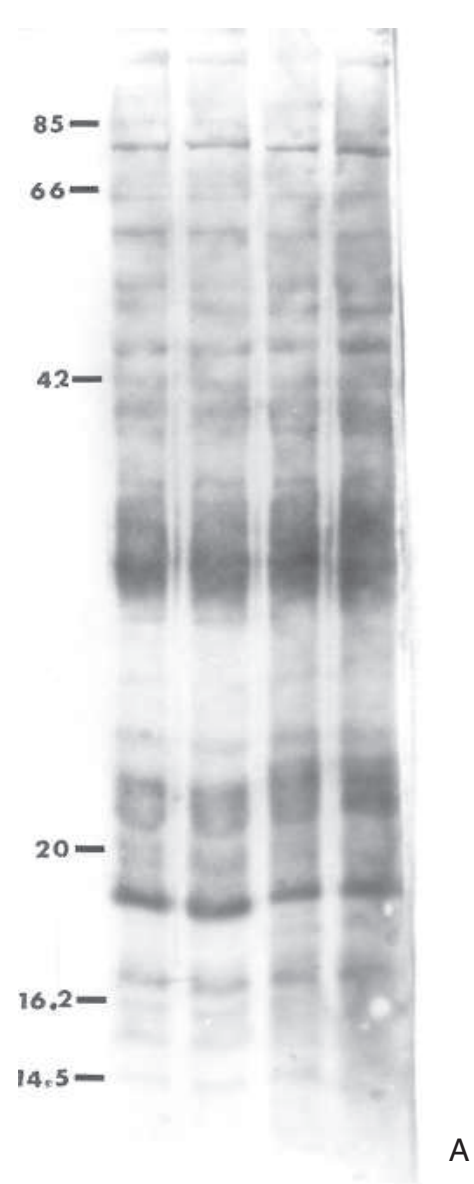

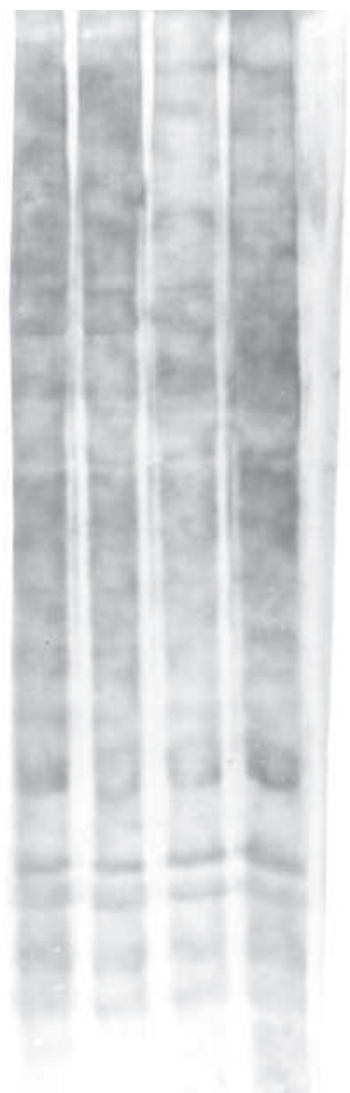

Fig. 2. - Western blot analysis with male and female somatic antigens of the sera from infected $\operatorname{dog}(\mathrm{A})$, and sera from uninfected $\operatorname{dog}(\mathrm{B})$. published on the immunodiagnosis of heartworm infections (Boto et al., 1984; Tamashiro et al., 1986; Ehrenberg et al., 1987; Scott et al., 1988; Hayasaki et al., 1994), these are not sufficient. The purpose of the present study was to demonstrate qualitatively the presence of serologically specific antigenic components in protein extract of adult $D$. immitis.

Tamashiro et al. (1986) identified surface antigens of D. immitis microfilariae by radioiodination. Specific antigens of molecular weights of 14 and $16 \mathrm{kDa}$ are found on the microfilariae surface. These molecules react with sera from $D$. immitis infected dogs (microfilaremic and occult forms), but not by sera from uninfected dogs or sera from dogs with potentially crossreactive nematode infection (Toxocara canis, Dipetalonema reconditum and Ancylostoma species). Scott et al. (1988) analyzed the surface antigens of adult D. immitis female and male parasites by SDS-PAGE. Dirofilaria immitis male and female parasites were found to have a limited number of surface-associated proteins (17.5, 16 and $14.5 \mathrm{kDa}$.) and glycoproteins (49 and $20 \mathrm{kDa}$ ). In addition, a 10 to $6 \mathrm{kDa}$ surface-associated glycolipid was identified. The glycolipid and the $14.5 \mathrm{kDa}$ surface protein were selectively released by the adult parasite during in vitro culture. Sera from $D$. immitis infected individuals reacted specifically with antigenic bands of 49, 20, 17.5 and $16 \mathrm{kDa}$, whereas the $14.5 \mathrm{kDa}$ and 10 to $6 \mathrm{kDa}$ bands were not observed in their study (Scott et al., 1988). It is interesting to note that Ehrenberg et al. (1987) found a $14 \mathrm{kDa}$ peptide among the parasite antigens found in the circulation of D. immitis infected animals. The $14 \mathrm{kDa}$ is considered a close value to $14.5 \mathrm{kDa}$, which was detected in our study and probably represent the same antigen. The $14.5 \mathrm{kDa}$ peptide reacted with the serum of infected dog. This is highly immunogenic and probably present in the circulation in the form of immunocomplexes.

Boto et al. (1984) used detergent extract antigens of adult $D$. immitis for the determination of antibody response by the sera obtained at different stage of the infection. They reported that antibody responses were developed against 200, 130, 100, 80, and $75 \mathrm{kDa}$ in occult or microfilaremic dogs at three months P.I. In addition to these molecules, 42, 38, 34, 21, 18, 16 and $15 \mathrm{kDa}$ were detected in sera obtained at six months P.I. from either group of dogs. Antibodies to P200 (an antigenic polypeptide of Mr $200 \mathrm{kDa}$ ), P130, P100, P80 
and P75 in the sera of occult and microfilaremic dogs declined steadily to background levels by 14 months post infection. In this present study, 85, 66, 20, 16.2 and $14.5 \mathrm{kDa}$ bands were detected. This findings indicated that low molecular weight region of somatic proteins (particularly bands below $20 \mathrm{kDa}$ ) may be related to the anti-parasitic mechanism as suggested so far (Ehrenberg et al., 1987; Scott et al., 1988; Hayasaki et al., 1994). These observations suggest that these low molecular weight peptides may be useful as diagnostic reagents, but further studies must be carried out to detect more specific bands. Determining the immune reactive protein bands for $D$. immitis infection in dogs by Western blotting may have importance in the studies concerning eradication of dogs via serologic studies in the future.

\section{REFERENCES}

Boto W.M.O., Powers K.G. \& Levy D.A. Antigens of Dirofilaria immitis which are immunogenic in the canine host: Detection by immuno-staining of protein blots with the antibodies of occult dogs. The Journal of Immunology, 1984, 133, 975-980.

Calvert C.A. Confirming a diagnosis of heartworm infection in dogs. Veterinary Medicine, 1987, 82, 232-237.

Ehrenberg J.P., TAmashiro W.K. \& ScOtT A.L. Dirofilaria immitis: Identification and characterization of circulating parasite antigens. Experimental Parasitology, 1987, 63, 205-214.

Grieve R.B., LoK J.B. \& Glickman L.T. Epidemiology of canine heartworm infection. Epidemiologic Reviews, 1983, 5, 220246.

HayAsaki M., NANAMURA F. \& KonNO K. Immunoblotting analysis of somatic components of Dirofilaria immitis. Journal of Veterinary Medical Science, 1994, 56, 1181-1183.

LAEMmLi U.K. Cleavage of structural proteins during the assembly of the head of bacteriophage T4. Nature, 1970, 227, 680-685.

LAIRD A. \& SMITH D.S. Homo sapiens beware... your zoonotic friends are not the only ones in danger of... dirofilariasis. http://www.stanford.edu/class/humbio103/ParaSites 2001/dirofilariasis/

Scott A.L., Diala C., Moraga D.A., Ibrahim M.S., Redding L. \& TAmashiro W.K. Dirofilaria immitis: Biochemical and immunological characterization of the surface antigens from adult parasites. Experimental Parasitology, 1988, 67, 307-323.

TAmashiro W.K., Ehrenberg J.P., Levy D.A. \& ScotT A.L. Antigenic peptides on the surface of Dirofilaria immitis microfilariae. Molecular Biochemistry of Parasitology, 1986, 18, 369-376.

Reçu le 29 septembre 2003 Accepté le $1^{\mathrm{er}}$ octobre 2004 